International Research Journal of Management, IT \& Social Sciences
Available online at https://sloap.org/journals/index.php/irjmis/
Vol. 6 No. 3, May 2019, pages: 11 17
ISSN: 2395-7492
https://doi.org/10.21744/irjmis.v6n3.622

\title{
The Ability of Organization Commitment and Moderate Worked Motivation by the Effect of Budget Goal Clarity in Budgetary Inaccuracy
}

\begin{tabular}{|c|c|}
\hline & $\begin{array}{r}\text { I Gusti Ayu Dewi Indira Sari } \\
\text { A.A.N.B. Dwirandra }\end{array}$ \\
\hline Article history: & Abstract \\
\hline $\begin{array}{l}\text { Received: } 18 \text { December } 2018 \\
\text { Accepted: } 31 \text { March } 2019 \\
\text { Published: } 16 \text { April } 2019\end{array}$ & $\begin{array}{l}\text { In term of designing activity and budgeting for organization, the goal of this } \\
\text { research is to explore and understand the effects of budget goal clarity on the } \\
\text { inaccuracy of budgeting that moderate by organizational commitment and } \\
\text { worker motivation. Population of research is all department under the } \\
\text { postgraduate program of Udayana University. Samples are choosing by total } \\
\text { sampling method and data that collected should meet with pre-request of }\end{array}$ \\
\hline $\begin{array}{l}\text { Keywords: } \\
\text { budget; } \\
\text { goal clarity; } \\
\text { inaccuracy; } \\
\text { job motivation; }\end{array}$ & $\begin{array}{l}\text { assumption test. Data were analyzed by Binary Logistic Regression Analysis. } \\
\text { The result of this research showed that: (1) budget goal clarity is negative } \\
\text { significant effect the budgeting unaccuracy; (2) organizational commitment } \\
\text { are increased the negative effect of budgeting goals on budget unaccuracy; (3) } \\
\text { worked motivation increased the negative effect of the clarity of budgeting on } \\
\text { budgeting unaccuracy. }\end{array}$ \\
\hline
\end{tabular}

2395-7492@ Copyright 2019. The Author. This is an open-access article under the CC BY-SA license (https://creativecommons.org/licenses/by-sa/4.0/) All rights reserved.

\section{Author correspondence:}

I Gusti Ayu Dewi Indira Sari,

Faculty of Economic and Business Udayana University, Bali, Indonesia.

Email address: igaindiradewi@gmail.com

\section{Introduction}

Technically, the estimation of future conditions will be an important consideration in budgeting. Internal conditions that are under control should be well accommodated. The problem that arises is that external changes are out of control, making it difficult to predict. This ability to look far ahead will determine the accuracy of the budget with its realization and help map the budget goal clarity (Kusuma, 2013).

Kenis (1979), states that there are several characteristics of the budgeting system. One of the characteristics of the budget is the clarity of budget targets. Budget goal clarity describes the scope of the budget that is stated clearly and specifically and understood by those responsible for its achievement. The existence of a clear budget target will facilitate budget managers to prepare budget targets (Zambrano et al., 2018).

\footnotetext{
a Faculty of Economic and Business Udayana University, Bali, Indonesia ${ }^{\mathrm{b}}$ Faculty of Economic and Business Udayana University, Bali, Indonesia
} 
In fact, it turns out that budget clarity is not necessarily linear and will increase budget accuracy. Kenis (1979), shows the relationship between the budget goal clarity and managerial performance shows significant results. Darma (2004), also supports the existence of a relationship between the budget goal clarity and performance in the context of local government. This is supported by Abdullah (2004), research which states that there is a significant relationship between the budget goal clarity and the performance accountability of government agencies. On the contrary, the results of Adoe (2002), study show that budget goal clarity does not significantly affect managerial performance. Jumirin (2001), shows that there is no significant relationship between the budget goal clarity and the performance accountability of government agencies.

The findings that indicate the inconsistency between one study and another, indicate the possibility of other variables that affect the relationship between the budget goal clarity and its impact. The inconsistency of the results of research on the effect of budget target clarity on Budgetary Inaccuracy shows the effect of other variables that can strengthen or weaken the so-called moderating variables (Sugiyono, 2017).

The concept of organizational commitment is a variable that plays an important role in the relationship between the budget goal clarity and the accuracy of the budget. Organizational commitment is a strong belief and support for the values and goals that the organization wants to achieve (Mowday et al., 1979). Based on the results of the study, it shows that the budget goal clarity and organizational commitment has a positive effect on the accuracy of the revenue and expenditure budget (Kusuma, 2013). In addition, organizational commitment can be a psychological aid in carrying out its organization to achieve expected goals (Nouri \& Parker, 1996; McClurg, 1999; Chong \& Chong, 2002; Wentzel, 2002; Darma, 2004). Officials who feel the budget target is clear will be more responsible if supported by the high commitment of the apparatus to the organization (agency). The apparatus will be more concerned with organizational interests than personal interests. This will encourage the apparatus to prepare a budget in accordance with the objectives to be achieved by the organization so that the accuracy of the budget will be achieved.

Motivation is a situation in a person that encourages the desire of individuals to carry out certain activities to achieve goals (Reksohadiprodjo \& Handoko, 1997). Motivation is basically a process that determines how much effort will be devoted to carrying out work. Motivation or encouragement to work is very decisive for the achievement of a goal, then humans must be able to foster the highest job motivation for employees in the company (Buhler, 2004). The motivation that exists in one's person will encourage someone to arrange a budget in accordance with the goals to be achieved by the organization so that the accuracy of the budget will be achieved.

\section{Literature Review}

\section{The Effect of Budget Goal Clarity on Budgetary inaccuracy}

Suhartono \& Solichin (2006), state that setting specific goals will be more productive than not setting specific goals that will encourage employees to do their best to achieve the desired goals. Increased budget goal clarity will be followed by a decrease in the inaccuracy of the budget in the Study Program within the Udayana University Postgraduate Program. Based on the description, the hypothesis proposed is as follows:

Ha1: Budget Goal Clarity negatively affects the tendency of budgetary inaccuracy

Organizational Commitment as Moderating the Effect of Budget Goal Clarity on Budgetary inaccuracy

The existence of predetermined goals is supported by high organizational commitment, so that each budget manager will prioritize the interests of the organization rather than personal or group interests and strive to achieve the targets set beforehand so that it has implications for achieving the right budget in the Study Program within the Udayana University Postgraduate Program. Based on the description, the hypothesis proposed is as follows:

Ha2: Organizational commitment increases the negative effect of the budget goal clarity on the tendency of budget inaccuracy.

\section{Job Motivation as Moderating the Effect of Budget Goal Clarity on Budget Inaccuracy}

Understanding motivation is closely related to the emergence of a tendency to do something in order to achieve goals (Buhler, 2004). Narmodo \& Wadji (2004), state that motivation is the relative strength of the impulse that arises in the employee to try optimally in achieving goals that are affected by the ability of the business to satisfy needs. Lutham \& Locke (1979), state that in fact the goal is something simple, but this simplicity cannot be interpreted simply or plainly but must be addressed with careful planning. Determination of specific goals, someone will be able to compare what has been done with the goal (goal) itself, and then determine where his position at that time. Goal-setting 
allows individuals to see current work results and compare them with past work results. This will create a separate motivation for individuals to try even better. Based on the description, the hypothesis proposed is as follows:

Ha3: Job motivation increases the negative effect of the budget goal clarity on the tendency of budget inaccuracies.

\section{Materials and Methods}

This research was conducted at the Study Program in the scope of the Udayana University Postgraduate Program. During the study in 2016, at the time the Udayana University Postgraduate Program still managed 35 Work Units, including 1 Postgraduate Program Secretariat and 34 Postgraduate Study Programs (Monodisciplinary and Multidisciplinary). The population in this study is the Financial Manager in the Study Program in the Scope of the Udayana University Postgraduate Program. The number of Study Programs in the Postgraduate Program Scope of Udayana University is 34 Study Programs and 1 Postgraduate Program Secretariat where the number of financial managers is 101 people, hereinafter referred to as a population. The data analysis technique used in this study is the Binary Logistic Regression Analysis Technique.

\section{Results and Discussions}

The magnitude of the coefficient of determination in the logistic regression model is indicated by the value of Nagelkerke R Square. The coefficient of determination is used to measure how much the model's ability to explain the independent variables (Ghozali, 2013). Results from Nagelkerke R Square can be seen in Table 1.

Table 1

Nagelkerke R Square

\begin{tabular}{ccc}
\hline-2 Log Likelihood & Cox \& Snell R Square & Nagelkerke R Square \\
\hline 11,996 & 0,247 & 0,737 \\
\hline
\end{tabular}

Secondary Data, 2019

Based on Table 1, it can be seen that Nagelkerke R Square is 0.737 which means that the variability of the dependent variable which can be explained by the independent variable is 73.70 percent, while the remaining 26.30 percent is effect by other variables outside the research model.

The Binary Logistic Regression Model can be formed by looking at the value of the parameter estimate in the variable in the equation. The equation model formed by entering the variable budget target clarity and the interaction of budget target clarity variables and organizational commitment variables and budget target clarity variables and job motivation variables with the regression results are presented in Table 2.

Table 2

Regression

\begin{tabular}{ccc}
\hline Variables & Coefficient & Significant \\
\hline $\mathrm{X}$ & -1.652 & 0.011 \\
$\mathrm{XM}_{1}$ & 0.011 & 0.045 \\
$\mathrm{XM}_{2}$ & 0.010 & 0.025 \\
Constanta & 35.804 & 0.037 \\
\hline
\end{tabular}

Secondary Data, 2019

The regression model formed based on the value of parameter estimation in the variable in the equation is as follows:

Ln $\underline{\mathrm{KAB}}=35,804-1,652 \mathrm{X}+0,011 \mathrm{XM}_{1}+0,010 \mathrm{XM}_{2+} \varepsilon^{-------------------(2)}$

$1-\mathrm{KAB}$

Sari, I. G. A. D. I., \& Dwirandra, A. (2019). The ability of organization commitment and moderate worked motivation by the effect of budget goal clarity in budgetary inaccuracy. International Research Journal of Management, IT and Social Sciences, 6(3), 11-17. https://doi.org/10.21744/irjmis.v6n3.622 


\subsection{The Effect of Budget Goal Clarity on Budgetary Inaccuracy}

The Ha1 hypothesis which states that budget goal clarity negatively affects the tendency of Budgetary Inaccuracy gets a significance value of 0.011 , which means that the value is greater than the significance level of $5 \%$ or 0.05 and the unstandardized coefficients of -1.652 means that budget goal clarity has a negative effect on the tendency of Budgetary Inaccuracy or in other words the higher the budget goal clarity will reduce the tendency of budget inaccuracies. Based on the exposure, the results of this hypothesis test accept the Ha1 hypothesis.

The results of this study are also in line with the results of the study of Suhartono \& Solichin (2006), stating that the existence of a clear budget target, it will be easier to account for the success or failure of the implementation of organizational tasks in order to achieve previously set goals and objectives. The results of this study are also the same as the results of a study conducted by Kusuma (2013), concluding that budget clarity has a positive effect on the accuracy of the revenue and expenditure budget.

\subsection{Organizational Commitment as Moderating the Effect of Budget goal clarity on Budgetary Inaccuracy}

The Ha2 hypothesis which states that organizational commitment increases the negative effect of the budget goal clarity on the tendency of inaccurate budget expenditures obtains a significance value of 0.045 , which means smaller than the significance level of $5 \%$ or 0.05 and the unstandardized coefficients of 0.011 means that commitment the organization is able to increase the negative effect of the budget goal clarity on the tendency of Budgetary Inaccuracy or in other words the higher the organizational commitment will reduce the tendency of budget inaccuracies. Based on the exposure, the results of this hypothesis test accept the Ha2 hypothesis.

The results of this study support the study of Eker (2007), which concluded that there is a positive and significant relationship of budgetary participation through an organizational commitment to managerial performance. The results of the study are in accordance with the results of the research of Suhartono \& Solichin (2006), Kusuma (2013), which states that organizational commitment acts as a moderating variable in the relationship between budget goal clarity and budgetary slack. Budget goal clarity if supported by a high organizational commitment to the organization (agency), will encourage budget managers to realize the budget in accordance with the goals to be achieved by the organization so as to reduce the tendency of budget inaccuracy, which means that organizational commitment is a contingency variable capable of influencing budget imprecision shopping. With the high organizational commitment to the organization, the lower the budget inaccuracy.

\subsection{Job Motivation as Moderating the Effect of Budget goal clarity on Budgetary inaccuracy}

The Ha3 hypothesis which states that job motivation increases the negative influence of the budget goal clarity on the inaccuracy of the budget gets a significance value of 0.025 which means it is smaller than the significance level of $5 \%$ or 0.05 and the constant value (Unstandardized Coefficients) of 0.010 means that job motivation able to increase the negative influence of the budget goal clarity on the tendency of inaccurate budget spending. or in other words the higher the job motivation will reduce the tendency of budget inaccuracies. Thus the results of this hypothesis test accept the Ha3 hypothesis.

Budget goal clarity if supported by the job motivation of the high budget manager for the organization (agency), will encourage the budget manager to try optimally in realizing the budget in accordance with the goals to be achieved by the organization, thereby reducing the tendency of budget inaccuracies, which means job motivation which is a contingency variable able to influence the tendency of budget inaccuracies. With the existence of high job motivation towards the organization, it will reduce the tendency of budget inaccuracies.

\section{Conclusion}

Budget goal clarity has a negative effect on the tendency of inaccurate budgetary expenditure in the Study Program within the Udayana University Postgraduate Program. Budget goal clarity is the extent to which the budget goals are clearly and specifically set with the objectives of the budget understood by those responsible for achieving these targets so as to reduce the tendency for inaccuracies in the budget. The increasing budget goal clarity will be followed by a decrease in the tendency of inaccurate budgetary expenditure in the Study Program within the Udayana University Postgraduate Program. 
Organizational commitment can increase the negative influence of the budget goal clarity on the inaccuracy of the Study Program budget within the Udayana University Postgraduate Program. This means that a stable organizational commitment and support with clear budget goals can reduce the tendency of budget inaccuracies. Managing a budget that has a clear budget target, will be more responsible if supported by a high budget manager's commitment to the organization (agency). Budget managers will be more concerned with organizational interests than personal interests. This will encourage budget managers to prepare budgets in accordance with the objectives to be achieved by the organization so that the budget will be accurate.

Job motivation can increase the negative influence of the budget goal clarity on the inaccuracy of the budget. This means that good job motivation and support with good budget clarity can reduce the tendency of budget inaccuracies. Determination of specific goals in a person will encourage the individual to be able to compare what has been done with the goal (goal) itself, and then determine where the position at that time. Goal-setting allows individuals to see current work results and compare them with past work results. This will give rise to a separate motivation for individuals to better try to achieve the accuracy of the stipulated budget.

\section{Limitation and Further Research}

This study has limitations, this research is limited to the variable clarity of the budget target, organizational commitment, and job motivation in relation to the inaccuracy of the budget, so that further research is expected to examine more deeply and not limited to the variable budget goal clarity, organizational commitment, and job motivation in relation to the inaccuracy of the budget, but need to add other variables. In addition, further research is expected to be able to use a broader range of research objects. Further research is also expected to develop the research analysis model to get more in-depth results.

\section{Conflict of interest statement and funding sources}

The authors declared that they have no competing interest. The study was financed by personal funding.

\section{Statement of authorship}

The authors have a responsibility for the conception and design of the study. The authors have approved the final article.

\section{Acknowledgments}

The authors would like to acknowledge the editor of IRJMIS for their support, valuable time, and advice in completing the present article.

Sari, I. G. A. D. I., \& Dwirandra, A. (2019). The ability of organization commitment and moderate worked motivation by the effect of budget goal clarity in budgetary inaccuracy. International Research Journal of Management, IT and Social Sciences, 6(3), 11-17. https://doi.org/10.21744/irjmis.v6n3.622 


\section{References}

Abdullah, H. (2004). Pengaruh Kejelasan Sasaran Anggaran, Pengendalian Akuntansi, Motivasi dan Sistem Pelaporan terhadap Akuntabilitas Kinerja Instansi Pemerintah pada Kabupaten dan Kota Daerah Istimewa Yogyakarta. (thesis). Yogyakarta: Program Pascasarjana UGM.

Adoe, M. H. (2002). Pengaruh karakteristik tujuan anggaran terhadap perilaku, sikap, dan kinerja aparat pemerintah daerah di Propinsi Nusa Tenggara Timur (Doctoral dissertation, [Yogyakarta]: Universitas Gadjah Mada).

ASYIKIN, J. (2002). Persepsi kepala instansi pemerintah terhadap otonomi daerah dan akuntabilitas kinerja (Doctoral dissertation, Universitas Gadjah Mada).

Buhler, P. (2004). Alpha Teach Yourself Management Skills. Edisi Pertama. diterjemahkan oleh Sugeng Haryanto, Sukono Mukidi, dan M. Rudi Atmoko. Jakarta: Prenada.

Chong, V. K., \& Chong, K. M. (2002). Budget goal commitment and informational effects of budget participation on performance: A structural equation modeling approach. Behavioral Research in Accounting, 14(1), 65-86. https://doi.org/10.2308/bria.2002.14.1.65

DARMA, E. S. (2004). Pengaruh kejelasan sasaran anggaran dan sistem pengendalian akuntansi terhadap kinerja manajerial dengan komitmen organisasi sebagai variabel pemoderasi pada pemerintah daerah:: Studi empiris pada Kabupaten dan kota se-Propinsi Daerah Istimewa Yogyakarta(Doctoral dissertation, Universitas Gadjah Mada).

Eker, M. (2007). The Impact of Budget Participation on Managerial Performance Via Organizational Commitment: A Study on The Top 500 Firms in Turkey. e-Journal Ankara Univesitesi SBF Dergisi.

Ghozali, I. (2006). Aplikasi analisis multivariate dengan program SPSS. Badan Penerbit Universitas Diponegoro.

Kenis, I. (1979). Effects of budgetary goal characteristics on managerial attitudes and performance. Accounting Review, 707-721.

Kusuma, E. A., \& Budiartha, I. K. (2013). Pengaruh Kejelasan Sasaran Anggaran, Komitmen Organisasi dan Ketidakpastian Lingkungan pada Ketepatan Anggaran (Studi Empiris di SKPD Pemerintah Provinsi Bali). E-Jurnal Ekonomi dan Bisnis Universitas Udayana.

Latham, G. P., \& Locke, E. A. (1979). Goal setting-A motivational technique that works. Organizational dynamics, 8(2), 68-80. https://doi.org/10.1016/0090-2616(79)90032-9

Latham, G. P., \& Steele, T. P. (1983). The motivational effects of participation versus goal setting on performance. Academy of Management Journal, 26(3), 406-417. https://doi.org/10.5465/256253

Locke, E. A. (1968). Toward a theory of task motivation and incentives. Organizational behavior and human performance, 3(2), 157-189. https://doi.org/10.1016/0030-5073(68)90004-4

Locke, E. A., \& Latham, G. P. (1984). Goal setting: A motivational technique that works!.

Mcclurg, L. N. (1999). Organisational commitment in the temporary-help service industry. Journal of Applied Management Studies, 8(1), 5.

Mowday, R. T., Steers, R. M., \& Porter, L. W. (1979). The measurement of organizational commitment. Journal of vocational behavior, 14(2), 224-247. https://doi.org/10.1016/0001-8791(79)90072-1

Nouri, H., \& Parker, R. J. (1996). The effect of organizational commitment on the relation between budgetary participation and budgetary slack. Behavioral Research in Accounting, 8, 74-90.

Reksohadiprodjo, S., \& Brodjonegoro, A. B. P. (1997). Ekonomi lingkungan: suatu pengantar. BPFE Yogyakarta.

Suhartono, E., \& Solichin, M. (2006). Pengaruh Kejelasan Sasaran Anggaran Terhadap Senjangan Anggaran Instansi Pemerintah Daerah Dengan Komitmen Organisasi Sebagai Pemoderasi. Padang: Simposium Nasional Akuntansi $I X$.

Sumbung, I. L., Falah, S., \& Antoh, A. (2017). Pengaruh Motivasi dan Disiplin terhadap Kinerja Pegawai dengan Pemberian Insentif sebagai Variabel Moderasi. Jurnal kajian ekonomi dan keuangan daerah, 2(1).

Tien, M. R. Sugiyono.(2014). Prinsip dan Proses Teknologi Pangan. Alfabeta: Bandung.

Wentzel, K. (2002). The influence of fairness perceptions and goal commitment on managers' performance in a budget setting. Behavioral research in Accounting, 14(1), 247-271. https://doi.org/10.2308/bria.2002.14.1.247

Zambrano, M. L. V., Barreto, M. D. L. A. C., \& Chica, T. K. M. (2018). Intervention of social work in political participation of women in forming process of neighborhood councils of canton Portoviejo. International Journal of Social Sciences and Humanities, 2(1), 134-146. https://doi.org/10.29332/ijssh.v2n1.104 


\section{Biography of Authors}

\begin{tabular}{|l|l||}
\hline & $\begin{array}{l}\text { I Gusti Ayu Dewi Indira Sari was born on Denpasar. She finished her study in Magister } \\
\text { Accounting at Udayana University and currently as an employee at Magister Architect } \\
\text { Udayana University in the financial field. } \\
\text { Email: igaindiradewi@gmail.com }\end{array}$ \\
\hline & $\begin{array}{l}\text { Dr. Drs. A. A. N. B. Dwirandra was born in Denpasar, December 23 } \\
\text { lecturer on Udayana University, Faculty of Economic and Business, Departement of } \\
\text { Accounting. He graduated his bachelor degree in Airlangga University (Surabaya, } \\
\text { Indonesia), Master Program in Gajah Mada University (Yogyakarta, Indonesia), } \\
\text { Doctoral Program in Brawijaya University, (Malang, Indonesia). } \\
\text { Email: dwirandra2012@gmail.com }\end{array}$ \\
\hline
\end{tabular}

Sari, I. G. A. D. I., \& Dwirandra, A. (2019). The ability of organization commitment and moderate worked motivation by the effect of budget goal clarity in budgetary inaccuracy. International Research Journal of Management, IT and Social Sciences, 6(3), 11-17. https://doi.org/10.21744/irjmis.v6n3.622 